JOURNAL OF SECURITY AND SUSTAINABILITY ISSUES

ISSN 2029-7017 print/ISSN 2029-7025 online

2019 June Volume 8 Number 4

http://doi.org/10.9770/jssi.2019.8.4(5)

Scopus

\title{
RESEARCH ON THE RELATION BETWEEN CONCEPTIONS OF THE STATE'S ECONOMIC AND FINANCIAL SECURITY: THEORETICAL ASPECT
}

\author{
Gintare Giriuniene $^{1 *}$, Gintaras Cernius², Lukas Giriunas ${ }^{3}$, Egle Jakunskiene ${ }^{4}$ \\ ${ }^{1,2,3}$ Faculty of Economics and Business, Mykolas Romeris University, Lithuania \\ ${ }^{4}$ LSC Girteka, Račiu g. 1, LT-03154, Lithuania \\ E-mail:*giriuniene@mruni.eu (corresponding author)
}

Received 16 January 2019; accepted 10 April 2019; published 30 June 2019

\begin{abstract}
The article analyses conceptions of both, the economic security and financial security of the state, in respect to a recent increase of attention given to assuring the state's economic security while emphasizing mostly the financial factor. Therefore, a thorough analysis on the two conceptions, as well as, on their interrelation, based on scientific literature, revealed that state's financial security and stability can reflect the economic security of the state only to some extent. The performed scientific practical research verified the hypothesis, which emerged during theoretical research, that financial security and stability cannot fully ensure the economic stability of the state.
\end{abstract}

Keywords: economic security, financial security, financial stability

Reference to this paper should be made as follows: Giriuniene, G.; Cernius, G.; Giriunas, L.; Jakunskiene, E. 2019. Research on the relation between conceptions of the state's economic and financial security: theoretical aspect, Journal of Security and Sustainability Issues 8(4): 609-616. http://doi.org/10.9770/jssi.2019.8.4(5)

JEL Classification: E60, F50, F52

\section{Introduction}

Given today's market circumstances when geopolitical environment of some countries is radically changing, the subjective attitude of citizens towards the state's economic security and its assurance is changing. A number of scientific researches performed on this matter highlight one of the most important aspects - the economic security, whereas other aspects, such as social, political, public security or ecologic security, are also researched while analyzing the state's security from the financial perspective. It is noteworthy to mention that the component of the state's financial security, identified by Hacker, J. S., Huber, G. A. et al. (2014), when placed into the calculation of economic security index (ESI), according to Bloom, D. E., Mahal, A. et al. (2010), confuses other evaluative aspects given the financial perspective. Therefore, when analyzing security aspects in scientific literature, the conclusion, referring to Lankauskiene, T., Tvaronaviciene, M. (2012), emerges that the state's security is affected and determined by financial reasons. As a result, Goryachev, K. S. (2003) claims that it is extremely complicated to separate financial security from economic and other security aspects of the state because it is assumed to be a unifying factor when conducting research on all of the state's security aspects. On the other hand, Karppinen H. (1998) claims that investors are forest owners who regarded their forest property as an asset and a source of economic security, providing financial security for old age. It is noted that in the scientific literature, plenty of opinions about state's economic and financial security and their interrelation has settled during these years. Therefore, contrapositions and generalities, existent in the linkage between financial and economic security conceptions in the scientific literature, determined the choice for this research area. 
Object for scientific research - conceptions of national economic security and financial security in the context of various aspects while assessing the state's security.

Objective of research - having performed the research on conceptions of the state's economic and financial security, to define financial security in the context of other security aspects.

In order to perform a successful and reliable research, the following tasks are set:

- To perform a thorough analysis of the scientific literature on the conceptions of the state's economic security and its financial security;

- To conduct a research on the interrelation between conceptions of the state's economic security and its financial security;

- To assess the generalized connections of the state's security aspects from the quantitative approach.

The study covers analysis of scientific research works, empirical researches and economic literature, as well as, the practical study on the conceptions of the economic and financial security of the state and the issues of their interrelatedness.

\section{The critical literature review and analysis}

Only recently, when financial crises are becoming more frequent and geopolitical environment is undergoing changes, countries undertook to pay more attention to issues related to economic and financial security. As a result, scientific discussions under these topics are surging and so are the differing conceptions and variations of a state's economic and financial stability. The essential limitedness of this research emerges due to economic security as a phenomenon being researched only on a micro level, whereas, economic security on a macro level remains under-researched, even though several authors, such as Kahler, M. (2004), Munteanu, C., Tamosiuniene, R. (2015), Shevchenko, O. M. et al. (2016), have analyzed it, but only through the identification of national security threats. There is almost unanimous agreement that the context of economic security conception can gain new aspects in terms of a rapid world globalization, and referring to, one of the main functions of state's regulation is supposed to be the assurance of the state's economic security (Tang, S. M. 2015; Strielkowski, W. et al. 2016; Strielkowski W. et al. 2017; Tvaronavičienė, M. 2018; Dudin et al. 2019; Cherchyk et al. 2019; Sasongko et al. 2019).

Especially relevant issue emerges in how to newly define the economic security conception and to what extent are currently applied quantitative assessment methods suitable. It is also worth considering that the state's economic security cannot be disembodied from other aspects of state's security. There is no basis for stating that a state, which territorial integrity and, at the same time, security is facing actual external threats, with which a state cannot cope efficiently, can be considered economically secure, because the conquerors can make use of the state's economic resources. Therefore, firstly it is essential to emphasize security in a broad sense and only afterwards to proceed analyzing the economic security of a state, its influencing factors, and aspects of quantitative security's assessment. Usually, security is perceived as "an absence of a threat to the object in question, especially when ensured by protection from harmful effects of another object or objects" (Kornilov, M., 2015). Whereas Glaser, C. L. (1997) states that the emergence of any risk is perceived as a negative thing that decreases the level of security. Other scientists define security as a state of object, in which the probability of its vulnerability is insignificant. Having applied all of the security principles, highlighted in scientific literature, to the formation of economic security conception, it can be stated that state's economic security relates to economic sustainability, i. e. when a state's economy has potential to grow, is resistant to external and internal shocks, and is able to foresee and react to the occurrence of various threats. The conducted research proves that with the lack of explicitness on the study field, the conception of economic security in scientific literature is portrayed through the prism of differing views (see Table 1). 
Table 1. Variations in conceptions of economic security

\begin{tabular}{|c|c|}
\hline Author & Conception \\
\hline Cable, V. (1995) & $\begin{array}{l}\text { Economic policy instruments which are used for purposes of aggression trade and investment boycotts, the } \\
\text { restriction of energy supplies. }\end{array}$ \\
\hline $\begin{array}{l}\text { von Geusau, F. A. M. A., } \\
\text { Pelkmans, J. (1982) }\end{array}$ & $\begin{array}{l}\text { The interests of a regime or economic actors to maintain influence or exert power in their international } \\
\text { relations. }\end{array}$ \\
\hline Raczkowski, K. (2012) & $\begin{array}{l}\text { A relatively sustainable endogenous and exogenous state of functioning of the international economy in } \\
\text { which a risk of imbalances is kept in a designated and acceptable organizational and legal standards and } \\
\text { principles of social coexistence }\end{array}$ \\
\hline $\begin{array}{l}\text { Grigoreva, E., Garifova, } \\
\text { L. (2015) }\end{array}$ & $\begin{array}{l}\text { Economic security is a complex socio-economic category, which is influenced by the continuously } \\
\text { changing environment of material production, external and internal threats of the economy. }\end{array}$ \\
\hline Pach, J. (2001) & $\begin{array}{l}\text { The ability of the economy to create and use interdependencies between the entities in order to boost } \\
\text { economic development to create such potential that can provide the ability to effectively adapt to changes } \\
\text { in the country in the global economy and to eliminate potential threats }\end{array}$ \\
\hline $\begin{array}{r}\text { Greb } \\
\text { Miliaus }\end{array}$ & $\begin{array}{l}\text { State and its entities ability (the political will and ability) to keep the economy facilities - systems in a } \\
\text { balance, that is necessary and sufficient condition to develop the state and its entities evolution }\end{array}$ \\
\hline T. Sviderske (2014) & $\begin{array}{l}\text { A never ending (and not a standstill) process, evidencing that (personal) economic security exists, and is } \\
\text { fixed and stable, directly and indirectly exert influence to the macroeconomic environment, which becomes, } \\
\text { for the sake of confidence, even more stable, secure and consecutively reproduces the economic security } \\
\text { feelings through "hard macroeconomic indexes" (inflation rate, employment) back to the micro economic } \\
\text { level. }\end{array}$ \\
\hline Hacker, J., et al. (2010) & $\begin{array}{l}\text { A preparation state of the economy for ensuring decent conditions for living and developing the personality, } \\
\text { the social-economic stability and the political military capability of the society and the country in order to } \\
\text { eliminate internal and external threats }\end{array}$ \\
\hline $\begin{array}{l}\text { Stankeviciene, J. et al. } \\
\qquad(2013)\end{array}$ & $\begin{array}{l}\text { A preparation for the economy, which lacks the historical primacy and intellectual currency assigned to } \\
\text { military security; it suffers from a diffuseness of both potential threats and remedies; and its content resists } \\
\text { clear categories of threat. }\end{array}$ \\
\hline Tang, S. M. (2015) & $\begin{array}{l}\text { A process that ensures a sufficient level of state finances, which enables the fighting against poverty, } \\
\text { unemployment and corruption. }\end{array}$ \\
\hline
\end{tabular}

The results obtained from the comparative analysis of the economic security conceptions presented in scientific literature enable stating that the conception depends not only on the applied context, but also on the attempt to emphasize one or the other security element. A group of scientists presents the economic security conception through the prism of the absence of threats. For example, Hacker, J., et al. (2010) assume that the economic security is as a preparation state of the economy for ensuring decent conditions for living and developing the personality, the social-economic stability and the political military capability of the society and the country in order to eliminate internal and external threats; apparently, it covers the outline of both internal and external threats. Whereas, Hipp, L. (2016), Angulo-Guerrero, M. J.-M.-G. (2017), Johnstone, C. P. (2013) define economic security only through the elimination of internal threats, and Franki, V. V. (2015), Popescu, M. F. (2014) present the economic security only through the prism of external threats, such as countries' dependency on energy resources, poverty, unemployment, migration, or corruption. Another group of scientists understands and portrays economic security as instruments of economic policy, the functioning of which is an inert, continuous and a timely process. However, various conceptions do not seem to relate the economic security to resistance and flexibility in the market, considering that market is facing systematic economic shocks at times that are shifting the demand for goods. For example, when state's expenses are declining, the business reacts to the diminishing governmental demand and in turn reduces its production; therefore, the state faces the decrease of its receivable revenues, as a result, the consumption is also decreasing. The business again reacts to the decline in demand and reduces the demand in goods even more, and this process just keeps repeating until a new balance is reached and the process settles down. Despite the existence of different conceptions of economic security, in order to reflect a versatile conception of economic security all of the identified crucial aspects of conception have to be highlighted. Thereof, the following conception emerges: economic security is an instrument of economic policy, the operation of which is an inert, continuous and a timely process that manifests through national, regional and worldwide aspects of security, and thereby ensures the control and management of internal and external threats (such as poverty, social and economic inequality, corruption, and etc.), which distinguishes in resistance to economic and financial shocks. Namely such a generalized formulation of the economic security conception covers a broader sense of economic security and makes the 
insight to its relation with a state's financial security possible. In the scientific literature, financial security is portrayed rather differently depending on the aspect being stressed. Distinct definitions of financial security are presented and described in the scientific works of Semjonova, N. (2012), Kaur, A. (2013), and other scientists (see Table 2).

Table 2. Variations in the conceptions of financial security

\begin{tabular}{|c|l|}
\hline Jiang, Y. (2010) & $\begin{array}{l}\text { An important part of national security, and it encompasses the ability to defend against domestic and } \\
\text { foreign attacks and international financial crises, and to maintain financial sovereignty }\end{array}$ \\
\hline Howell, R. T. et al. (2013) & An important outcome of socio-economic status (e.g., income, wealth, savings, lack of debt, etc.) \\
\hline Knights, D. (1997) & $\begin{array}{l}\text { A condition and consequence of the discursive formation of the modern subject and the power relations } \\
\text { in which subjectivity is embedded. }\end{array}$ \\
\hline $\begin{array}{c}\text { Pitt-Catsouphes, M., } \\
\text { Smyer, M. A. (2005) }\end{array}$ & A balance between financial assets and expenses \\
\hline Peeters, H. (2005) & A global public good: no one is required to maintain it but everybody can benefit from it \\
\hline $\begin{array}{c}\text { Pankow, D., } \\
\text { O’Neill, B. (2008) }\end{array}$ & The ability to meet day-to-day expenses while saving and investing for tomorrow \\
\hline Kaur, A. (2013) & Is an important type of safety need \\
\hline $\begin{array}{c}\text { Zheng-xiao, } \\
\text { W. A. N. (2005) }\end{array}$ & Is an important strategic significance to protect one country's security \\
\hline $\begin{array}{c}\text { Greenfield, C., } \\
\text { Williams, P. (2001) }\end{array}$ & $\begin{array}{l}\text { An important element of the government of the self under neo-liberalism, a self who is "obliged to be } \\
\text { free" }\end{array}$ \\
\hline Wei, L. I. U. (2009) & Vital importance to a nation's economic safety, political stability and sovereignty maintenance \\
\hline $\begin{array}{c}\text { Jureviciene, D., } \\
\text { Klimaviciene, A. (2008) }\end{array}$ & One of the main objectives of financial planning \\
\hline
\end{tabular}

As the analysis of financial security conception shows, a variety of opinions regarding the concept of financial security and numerous differing approaches that place emphasis on one or the other aspect have been presented so far. The given conceptions of financial security cover both monetary, economic, social, political, and national defense aspects, which in turn can be divided into two groups - political or practical - depending on the viewpoint they reflect.

\section{The course of the study and results}

Therefore, two focus points for approaching financial security emerge. One of them usually manifests through the political approach and indicates that financial security is an inclusion into national security, defense and sovereignty where financial interests are the basis of focus. This is proved by Burgess, J. P. (2012), who claims that the assurance of the satisfactory funding for the appointed areas enables achieving an adequate national financial security. At this point, the second focus of attention emerges, which indicates that financial security is the connecting piece of all security elements, including the economic security, which also maintains the entire national security without distinguishing its different elements (see Figure 1). 


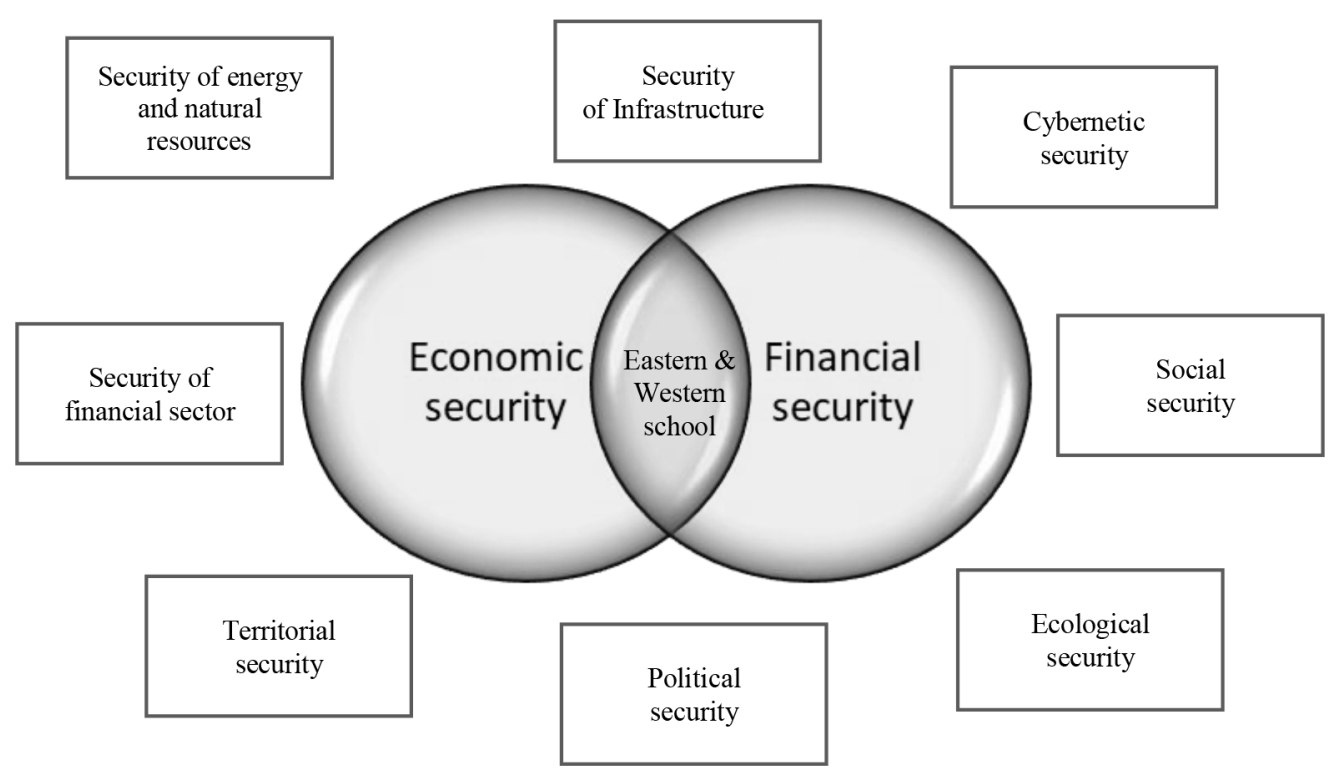

Fig. 1. Interrelation of national, economic and financial security

The scientific literature analysis confirmed that such an approach, which is presented in Figure 1, is not sufficient for a profound understanding of both economic and national security. The financial component is, in fact, integrally intertwined with each of the national security aspects (economic, territorial, cybernetic, etc.) and is a factor influencing each part of the security. At the same time, each of the elements determines the level of financial security, i.e. the system portrays it as a consequence. Hence, a better visualization of the concept of national security would be obtained by applying multidimensional matrix, in which financial security would be one of the dimensions. As a result, such a newly structured viewpoint that depicts the interrelation of economic and financial security would enable stating that the relation between these two components cannot be separated due to the identified conceptual mixture, which shows that financial security is inconceivable without economic security and vice versa. On the other hand, assuming a practical perspective, when financial security is understood only as a certain funding flow, any research on modern financial measures would inevitably raise issues related to risk management of security and economic security. It is important to emphasize that the analysis of financial security and economic security conceptions revealed that two approaches towards both of the conceptions exist - the Eastern and the Western. The Eastern approach, contrary to the Western approach, does not identify the security of banks with financial security. The Eastern school also places significantly more emphasis on the importance of the territorial security while assessing the financial security, whereas the Western school is oriented only to the banking sector. Therefore, such research results also enable stating that the two schools possess two distinct viewpoints for approaching financial and economic security; therefore, distinct elements of national security and their input is placed in shaping a state's economic and financial security. Nevertheless, financial security and economic security are too closely related and since there is no clear-cut distinction between the two phenomena, researches happen to analyze them in an integral manner.

\section{Concluding remarks}

The research on the economic security and financial security conceptions in the context of numerous aspects involved in assessing the security of a state revealed that during the years a variety of views regarding the two conceptions and their interrelatedness had settled. It is noted that two distinct approaches towards the interaction of the two conceptions exist - the Eastern and the Western. The Eastern approach pays more attention to the context of social and territorial security, whereas the Western approach assumes only one area for the interaction of the two conceptions and it is the security of banks. Therefore, the obtained relation between the conceptions of economic security and financial security grounded the statement that these two components cannot be clearly detached at the least due to the identified conceptual confusion. 


\section{References}

Angulo-Guerrero, M. J.-M.-G. (2017). How Economic Freedom Affects Opportunity and Necessity Entrepreneurship in the OECD Countries. Journal of Business Research 73, 30-37. https://doi.org/10.1016/j.jbusres.2016.11.017

Bloom, D. E., Mahal, A., Rosenberg, L., Sevilla, J. (2010). Economic Security Arrangements in the Context of Population Ageing in India. International Social Security Review 63, 59-89. https://onlinelibrary.wiley.com/doi/pdf/10.1111/j.1468-246X.2010.01370.x

Burgess, J. P. (2012). Handbook of New Security Studies. New York: Routledge, 328.

Cable, V. (1995). What is International Economic Security? International Affairs 71, 305-324. https://www.jstor.org/stable/2623436

Cherchyk, L., Shershun, M., Khumarova, N., Mykytyn, T., Cherchyk, A. 2019. Assessment of forest enterprises' performance: integrating economic security and ecological impact. Entrepreneurship and Sustainability Issues 6(4), 1784-1797. http://doi.org/10.9770/ jesi.2019.6.4(17)

Dudin, M.N., Frolova, E.E., Protopopova, O.V., Andrey Alievich Mamedov, A.A., Odintsov, S.V. 2019. Study of innovative technologies in the energy industry: nontraditional and renewable energy sources. Entrepreneurship and Sustainability Issues 6(4), 1704-1713. http://doi.org/10.9770/jesi.2019.6.4(11)

Franki, V. V. 2015. Energy Security, Policy and Technology in South East Europe: Presenting and Applying an Energy Security Index to Croatia. Energy 90, 494-507. https://doi.org/10.1016/j.energy.2015.07.087

Glaser, C. L. 1997. The Security Dilemma Revisited. World Politics, 171-201. http://www.jstor.org/stable/25054031

Goryachev, K. S. 2003. Financial Security. The Essence and Role in the System of Economic Security. Economist 8, 65-67.

Greenfield, C., Williams, P. 2001. Financial Advertising and Media Rhetoric. Southern Review: Communication, Politics \& Culture 34, 44. https://search.informit.com.au/documentSummary; $\mathrm{dn}=741168790675060$

Grebliauskas A., Miliauskas G. 2008. Valstybės Valdymo Makro Strategijos Formavimas [Macro Strategy formation on State Management]. Organizacijų vadyba: sisteminiai tyrimai [Organizational Management: Systematic Research]. 47, 55-71. https:// eltalpykla.vdu.lt/bitstream/handle/1/36542/ISSN2335-8750_2008_N_47.PG_55-71.pdf?sequence=1\&isAllowed=y

Grigoreva, E., Garifova, L. 2015. The Economic Security of the State: the Institutional Aspect. Procedia Economics and Finance 24, 266-273. https://doi.org/10.1016/S2212-5671(15)00658-9

Hacker, J. S., Huber, G. A., Nichols, A., Rehm, P., Schlesinger, M., Valletta, R., Craig, S. 2014. The Economic Security Index: a New Measure for Research and Policy Analysis. Review of Income and Wealth 60, 5-32. https://doi.org/10.1111/roiw.12053

Hipp, L. 2016. Insecure times? Workers' Perceived Job and Labor Market Security in 23 OECD Countries. Social Science Research 60, 1 - 14. https://doi.org/10.1016/j.ssresearch.2016.04.004

Howell, R. T., Kurai, M., Tam, L. 2013. Money Buys Financial Security and Psychological Need Satisfaction: Testing Need Theory in Affluence. Social Indicators Research 110, 17-29.

Jiang, Y. (2010), Response and Responsibility: China in East Asian Financial Cooperation. The Pacific Review 23, 603-623. https://doi. org/10.1080/09512748.2010.521850

Johnstone, C. P. (2013), A techno-Economic Analysis of Tidal Energy Technology. Renewable Energy 49, 101 - 106. http://www. sciencedirect.com/science/article/pii/S0960148112000651

Jureviciene, D., Klimaviciene, A. (2008), Theoretical Aspects of Life-Cycle Personal Finances Management. Business: Theory \& Practice 9, 22-32. https://btp.press.vgtu.lt/article/14165/download/pdf/

Kahler, M. 2004. Economic Security in an Era of Globalization: Definition And Provision. The Pacific Review 17, 485-502. https://doi. org/10.1080/0951274042000326032

Kaur, A. 2013. Maslow's Need Hierarchy Theory: Applications and Criticisms. Global Journal of Management and Business Studies 3, 1061-1064. https://www.ripublication.com/gjmbs_spl/gjmbsv3n10_03.pdf

Knights, D. 1997. Governmentality and Financial Services: Welfare Crises and the Financially Self-Disciplined Subject. In Regulation and Deregulation in European Financial Services. London: Palgrave Macmillan, 216-235. https://doi.org/10.1007/978-1-349-14000$8 \_11$ 
Kornilov, M. 2015. Economic Security as a Scientific Category. European Journal of Economics and Management Sciences 4, 59-64. https://cyberleninka.ru/article/n/economic-security-as-a-scientific-category

Lankauskiene, T., Tvaronaviciene, M. 2012. Security and sustainable development: approaches and dimensions in the globalization context. Journal of Security \& Sustainability Issues, 1, 287-297. https://doi.org/10.9770/jssi.2012.1.4(5)

Munteanu, C., Tamosiuniene, R. 2015. Modern Approaches in Quantifying Economic Security: Case Sudy of Estonia, Latvia, Lithuania and Republic of Moldova. Journal of Security and Sustainability Issues 4, 596-610. https://doi.org/10.9770/jssi.2015.4.4(2)S

Pach, J. 2001. Bezpośrednie Inwestycje Zagraniczne w Świetle Bezpieczeństwa Ekonomicznego na Przykładzie Polski w Latach Dziewięćdziesiątych XX Wieku (No. 309) [Direct Foreign Investments in the Light of Economic Security on the Polish Example in the XX Century]. Wydawn: Naukowe Akademii Pedagogicznej, 278. http://hdl.handle.net/11716/2327

Pankow, D., O’Neill, B. 2008. Extension Financial Security For All: a Community of Practice to Increase Financial Literacy. Journal of Extension 46. https://www.joe.org/joe/2008june/a3.php

Peeters, H. 2005. Sustainable Development and the Role of the Financial World. In The World Summit on Sustainable Development. Dordrecht: Springer, 241-274. https://doi.org/10.1007/1-4020-3653-1_11

Pitt-Catsouphes, M., Smyer, M. A. 2005. Older Workers: What Keeps Them Working. Issue Brief, 1. https://dlib.bc.edu/islandora/ object/bc-ir:100893/datastream/PDF/view

Poyda-Nosyk, N. 2017. Financial Security of Ukraine in Conditions of European Integration. Науковий Вісник Полісся Чернігівського Національного Технологічного Університету 9, 192-196. http://journals.uran.ua/nvp_chntu/article/view/101039/96261

Popescu, M. F. 2014. Energy Security - a Part of the Economic Security. Managementul Intercultural Vol XVI 31, 289 - 296. https:// ideas.repec.org/a/cmj/interc/y2014i31p289-296.html

Sasongko, G., Huruta, A.D., Wardani, A. 2019. Does the Wagner's Law exist in a strategic national area? An evidence from KedungsepurIndonesia. Insights into Regional Development 1(2): 99-117. https://doi.org/10.9770/ird.2019.1.2(2)

Semjonova, N. (2012), Structure of the National Debt, Credit Rating and State Financial Security. In: 53rd International Riga Technical University Conference „Scientific Conference on Economics and Enterpreneurship” (SCEE’2012): Proceedings, Latvia, Rīga, 12-16 October, 2012. Riga: RTU, 1-6.

Shevchenko, O. M., Dyatlov, A. V., Kurmalieva, Z. K., Volkov, Y. G., Popov, A. V. (2016), Economic Globalization: Challenges and Threats of the Russian National Security. International Journal of Economics and Financial Issues 6, 20-25. http://www.econjournals. com/index.php/ijefi/article/view/2844

Stankeviciene, J., Sviderske, T., Miecinskiene, A. (2013), Relationship between Economic Security and Country Risk Indicators in EU Baltic Sea Region Countries. Entrepreneurial Business and Economics Review 3, 21-33.

Strielkowski, W., Lisin, E., Astachova, E. 2017. Economic sustainability of energy systems and prices in the EU. Entrepreneurship and Sustainability Issues 4(4), 591-600. http://dx.doi.org/10.9770/jesi.2017.4.4(14)

Strielkowski, W., Lisin, E., Tvaronavičienè, M. 2016. Towards energy security: sustainable development of electrical energy storage. Journal of Security and Sustainability Issues 6(2): 43-52. http://dx.doi.org/10.9770/jssi.2016.6.2(4)

Sviderske, T. (2014), Country Risk Assessment in Economic Security and Sustainability Context. Vilnius: Technika, 132.

Tang, S. M. 2015. Rethinking Economic Security in a Globalized World. Contemporary Politics 21, 40-52. https://doi.org/10.1080/13 569775.2014 .993910

Tvaronavičienè, M. 2018. Toward efficient policy making: forecasts of vulnerability to external global threats. Journal of Security and Sustainability Issues 7(3), 591-600. https://doi.org/10.9770/jssi.2018.7.3(18)

Von Geusau, F. A. M. A., Pelkmans, J. (1982), National Economic Security: Perceptions, Threats and Policies. Versions of the Papers Presented at the Annual Colloquium, John F. Kennedy Institute, Center for International Studies, 7-10 May, 1980. John F. Kennedy Institute.

Raczkowski, K. 2012. Percepcja Bezpieczeństwa Ekonomicznego i Wyzwania Dla Zarządzania Nim w XXI Wieku. Bezpieczeństwo ekonomiczne, Wyzwania dla zarządzania państwem. [Perception of Economic Security and Challenges for Management in the 21st Century. Economic Security, Challenges for the Management of the State]. Oficyna a Wolter Kluwers business, Warszawa. 
Wei, L. I. U. 2009.Theoretical Reflections on CHEN Yun's Precondition of Financial Security. Journal of Jiangsu Polytechnic University 4. http://en.cnki.com.cn/Article en/CJFDTOTAL-JSSB200904009.htm

Zheng-Xiao, W. A. N. 2005. Research On the Chinese Financial Security Problems in the Background of Economic Globalization. Journal of Henan Normal University 4. http://en.cnki.com.cn/Article_en/CJFDTOTAL-HNSK200504012.htm 